\title{
LA CONSTRUCCIÓN MEDIÁTICA DE LA MUERTE
}

\author{
Juan Carlos Herranz* \\ Mónica Lafon**
}

A Carolina Sesto Calleja

RESUMEN: A partir de la observación de que la muerte era construida mediáticamente de distinta manera en dos catástrofes naturales -tsunami de Indonesia y huracán Katrina en Nueva Orleans-, elaboramos un metadiscurso, a partir del discurso periodístico que remitiese a los fundamentos filosóficos y antropológicos que preceden a la construcción de dichas representaciones. Para ello, se convoca a la filosofía, a la antropología de la muerte y a la semiótica en su punto de convergencia.

$$
\text { sose }
$$

ABSTRACT: From the examination that the image of death was mediatically constructed in different ways when referring to two natural catastrophes -the cases of the tsunami in Indonesia and the hurricane Katrina in New Orleans-, we will attempt to understand the construction of these narratives, so we can shed light upon the philosophical and anthropological foundaments that precede these representations. We will try to do so from a complex perspective based on the point of convergence for philosophy, anthropology and semiotics.

PALABRAS CLAVE: muerte, catástrofe natural, hiperrealidad, filosofía, antropología, semiótica. KEYWORDS: death, natural catastrophe, hiperreality, philosophy, anthropology, semiotics. RECEPCIÓN: 19 de octubre de 2007. ACEPTACIÓN: 22 de mayo de 2008.

* Departamento Académico de Estudios Generales, ITAM.

** Concordia University, Canada. 
La reproducción total o parcial de este artículo se podrá hacer si el ITAM otorga la autorización previamente por escrito. 


\section{LA CONSTRUCCIÓN MEDIÁTICA DE LA MUERTE*}

Ni el hombre blanco está exento de su destino. Jefe indio Seattle

\section{Introducción}

\section{Cuando Heidegger escribe que} somos-para-la-muerte, y que tan sólo podemos vivir la autenticidad de la existencia a partir de la asunción radical de nuestro destino mortal, ${ }^{1}$ está tratando de esbozar una concepción de la muerte que se opone radicalmente al sueño último de la modernidad, que por medio de la ciencia, ha soñado - piénsese en la criogenización o en la clonación- vencer, ni más ni menos, que a la mismísima muerte.

Escribe literalmente Heidegger:

El Dasein está constituido por la aperturidad, esto es, por un comprender afectivamente dispuesto. El estar vuelto propiamente hacia la muerte no puede esquivar la posibilidad más propia e irrespectiva, encubriéndola en esta huida y reinterpretándola en función de la comprensión común del uno. El proyecto existencial de un modo propio de estar vuelto hacia la muerte deberá destacar, por consiguiente, aquellos momentos de semejante estar que lo constituyen como un comprender de la muerte, en el sentido de un estar vuelto no rehuyente ni encubridor hacia la posibilidad ya caracterizada." 2

* El título original es: "La construcción mediática de la muerte. Un estudio desde la filosofía, la antropología y la semiótica", reducido por razones de espacio.

${ }^{1}$ Remitimos al lector en especial al parágrafo 53 de Ser y Tiempo, Heidegger, Ser y Tiempo, 2003, Madrid, Trotta.

${ }^{2}$ Heidegger, op. cit., p. 280. Las cursivas son de Heidegger, también en la siguiente cita. 
De modo que "la muerte es la posibilidad más propia del Dasein. El estar vuelto hacia esta posibilidad le abre al Dasein su más propio poder-ser, en el que está puesto radicalmente en juego."”3

La modernidad occidental, a diferencia de otras culturas, parece estar construida para evitar cualquier rastro del paso del tiempo-desde la cosmética y las cirugías plásticas, hasta, tal como observaba Jesús Ibáñez, ${ }^{4}$ la obsesión cotidiana por limpiar hasta la más diminuta mota de polvo-y muy especialmente, para evitar la idea de que un día, como diría Sófocles, el país de la muerte pueda detener nuestra carrera:

Numerosas son las maravillas del mundo, pero la más grande de las maravillas es el hombre $[\ldots]$

Es el ser de los mil recursos. Jamás el porvenir lo toma por sorpresa.

Conoce el arte de escapar a los males incurables.

Sólo el país de la muerte puede detener su carrera. ${ }^{5}$

En este texto griego podemos encontrar ya las raíces de ciertos rasgos de lo que será la modernidad occidental: por un lado, la distinción radical entre hombre y mundo, que se traducirá en el divorcio entre sujeto y objeto, hombre y naturaleza; ${ }^{6}$ por otro, la concepción extremadamente narcisista del hombre y su sueño acerca de la potencia de su razón, que se convierte en poder (recursos) y muy especialmente en capacidad de predicción (jamás el porvenir lo toma por sorpresa), lo que sirve a Horkheimer y Adorno para establecer la crítica radical de la modernidad occidental. ${ }^{7}$

${ }^{3}$ Heidegger, op. cit., p. 282.

${ }^{4}$ Jesús Ibáñez, Por una sociología de la vida cotidiana, Madrid, Siglo XXI.

${ }^{5}$ S., Ant., 332 s.

${ }^{6}$ Horkheimer y Adorno, La dialéctica de la Ilustración, 2001, Madrid, Trotta, p. 59-95.

7 "Si quisiéramos hablar de una enfermedad que se apodera de la razón, no debería entenderse esa enfermedad como si hubiese atacado a la razón en algún momento histórico, sino como algo inseparable de la esencia de la razón dentro de la civilización, tal como hasta ahora la hemos conocido. La enfermedad de la razón tiene sus raíces en su origen, en el deseo del hombre de dominar la naturaleza [...]. Desde los tiempos en que la razón se convirtió en 
Vemos, asimismo, la distinción, también absoluta, entre vida y muerte, entendida ésta como aquello que inter-rumpe, es decir aquello que supone la ruptura entre dos entidades: la carrera de aquel ser maravilloso, llamado hombre, y su fatal destino. Compárese con la perspectiva budista, donde la relación entre el hombre y naturaleza, la vida y muerte, no estarían definidas por la ruptura, sino que constituyen más bien distintos aspectos de un mismo continuo y donde la apuesta vital y filosófica no es por la carrera, como en Occidente, sino por la quietud.

Ahora bien, cuando la razón no es capaz de predecir, como en el caso de los catástrofes naturales, ${ }^{8}$ la primera consecuencia es de carácter epistemológico: se vuelven a perfilar los límites de la razón, la imposibilidad de su omnipotencia: "Una catástrofe natural es un peligro para el orden establecido, no solamente por el desorden real que provoca, sino también por el golpe que asesta a toda racionalidad soberana, así como política." Como dice Baudrillard: la razón no puede soportar aquello que se le escapa, y por consiguiente "todo desarreglo se interpreta como maleficio [...] como ataque al orden social". ${ }^{10}$

La segunda consecuencia es de carácter antropológico: se impone cierta construcción cultural ante ese país de la muerte que de pronto irrumpe de forma descomunal, porque tal como dice Louis-Vincent Thomas, existe una muerte biológica y una muerte cultural, así la tanatología se ocupa de observar los rituales y creencias tranquilizadoras de cada sociedad a la hora de la muerte. Los medios de comunicación desempeñan un papel fundamental en la construcción y/o reproducción de los imaginarios colectivos, de modo que en este ensayo preguntamos

instrumento de dominio de la naturaleza humana y extrahumana por el hombre-esto es, desde sus más tempranos comienzos-, su propia intención de descubrir la verdad se vio frustrada", Horkheimer, Crítica de la razón instrumental, 1973, Buenos Aires, Sur, p. 184.

${ }^{8}$ La teoría del caos emerge como teoría para predecir lo que en paradigmas clásicos se le escapaba a la ciencia, como los aspectos meteorológicos o la trayectoria del humo de un cigarrillo.

9 J. Baudrillard El intercambio simbólico y la muerte, 1993, Caracas, Monte Ávila Editores, p. 188.

${ }^{10}$ Ibid. 
cómo se construye la muerte en los medios de comunicación en el caso de los desastres naturales, en específico, en la fotografía de prensa, y tratamos de entender cuáles son los fundamentos filosóficos y antropológicos que preceden a dichas construcciones. Nuestra intención es, al menos, elaborar un metadiscurso sobre el discurso periodístico. En definitiva, desde el punto de encuentro de la filosofía, la antropología y la semiótica de la imagen, intentaremos abordar el estudio de aquello que Roland Barthes definió cómo el sentido obtuso de las imágenes, en esta ocasión, de las imágenes de dos casos particulares: la representación mediática de la muerte debido a un tsunami y la construcción de la muerte en las inundaciones de Nueva Orleans.

\section{La muerte}

Los orígenes del tabú de la muerte en Occidente o una crisis metafísica

Sin duda la metafísica predominante en Occidente durante siglos ha sido la metafísica cristiana de inspiración platónica, una concepción filosófica dualista que suponía que si, tras la muerte, el alma estaba suficientemente purificada, podría continuar una vida plena más allá del mundo sensible, liberándose el alma de la cárcel del cuerpo que representa un obstáculo para el conocimiento. Así, Platón escribe que el verdadero conocimiento tan sólo se puede tener después de la muerte:

Y también por culpa [del cuerpo] no encontramos tiempo para filosofar [...] si alguna vez vamos a poseer limpiamente un objeto de conocimiento, nos será necesario prescindir del cuerpo [...] Entonces obtendremos con seguridad [...] la sabiduría. Y esto solo ocurrirá cuando hayamos muerto. ${ }^{11}$

${ }^{11}$ Platón, “Fedón”, en Diálogos, 1996, México, Porrúa, p. 394. 
Al igual que en la tradición cristiana, la concepción de la muerte no sólo no suponía un fin absoluto de la existencia, sino que podía ser el camino hacia un mundo más puro, más hermoso, más perfecto, constituyendo esto una 'estrategia tranquilizante' tanto para el individuo que espera su muerte como para el que entierra al difunto. En esta filosofía no tiene por qué existir el pánico, ni constituir la muerte un tabú, de tal manera que la muerte no es ocultada; sin embargo, hoy la muerte es distinta. Escribe Thomas sobre los cambios de las actitudes frente a la muerte en Occidente:

Los progresos espectaculares de las ciencias y las técnicas; la reorganización de ciertas estructuras sociales, particularmente de la familia; el establecimiento de una civilización capitalista industrial basada en la rentabilidad y el beneficio, generaron transformaciones fundamentales: desacralización, desocialización, nueva concepción de la enfermedad, de la muerte, de la salud, primacía de lo económico, tabú creciente respecto a la muerte y al duelo, son todos puntos importantes que han llevado a creer en la existencia, hoy, de una muerte cambiada. ${ }^{12}$

Así los nuevos ritos de la nueva sociedad occidental estarían caracterizados por la simplificación, la desaparición, la privatización, la tecnificación y profesionalización (beneficio económico), el cambio de lugares, la disimulación y la reducción:

La vida urbana, con sus exigencias relativas al tiempo, el espacio, la rentabilidad y el lucro, y la reducción de la familia al grupo formado por la pareja y sus hijos, han modificado apreciablemente los ritos de antaño [...] sobre todo en los Estados Unidos, donde, después de haberse deshecho rápidamente del cadáver [...], los deudos se limitan a reunir algunos íntimos para orar en común. Otros se han vuelto obsoletos [...] como el acompañamiento del moribundo y el prolongado velatorio del cadáver; o han sido prohibidos directamente, como el paso del cortejo fúnebre por el centro de la ciudad. ${ }^{13}$

${ }^{12}$ Louis-Vincent Thomas, Antropología de la muerte, 1993, México, FCE, p. 407.

${ }^{13}$ Louis-Vincent Thomas, La muerte, 1991, Barcelona, Paidós, p. 128. 
¿Cuál es el origen de esa muerte cambiada? Es el cambio de concepción filosófica respecto a la muerte, cuyo origen tratamos de esbozar a continuación.

\section{¿Y si es Dios quien muere?}

Sabemos que lo que Nietzsche llama la muerte de Dios no es sino la crisis del discurso religioso, crisis que arranca posiblemente cuando Copérnico afirma el movimiento de la tierra alrededor del sol, abandonando la idea de que la tierra es el centro del universo; se radicaliza en el siglo XIX cuando las teorías de Darwin sugieren, asimismo, que el hombre ya no era la especie elegida por Dios, sino una especie entre otras, todas consecuencia de un proceso evolutivo.

Si la idea de Dios inspiró durante siglos el orden social occidental, desde los aspectos macro (Papados, relaciones entre Iglesia y Estado, etc.), hasta los aspectos micro (como escribe Nietzsche en El Anticristo, la Iglesia regulaba los momentos fundamentales de un individuo: mediante el bautizo, el nacimiento, mediante la boda, la reproducción y mediante el sepelio, la muerte), ¿qué sucede, entonces, cuando Dios muere? Tal es la pregunta que se hace Nietzsche:

El loco se colocó entre ellos y los fulminó con la mirada. ¿A dónde se ha ido Dios? [...] iNosotros lo hemos matado! [...] ¿Qué hemos hecho cuando hemos soltado la cadena que unía esta tierra con el sol? ¿A dónde va ésta ahora? ¿A dónde vamos nosotros mismos? ¿Lejos de todos los soles? ¿No caemos sin cesar? ¿Hacia delante, hacia atrás, de lado, de todos lados? ¿Hay todavía un arriba y un abajo? ¿No marchamos errantes como por una nada infinita? ¿No sentimos el soplo del vacío sobre nuestro rostro? [...] ¿Quién nos limpiará esta sangre? [...] ¿Qué expiaciones, qué juegos sagrados estaremos forzados a inventar? ${ }^{14}$

El texto de Nietzsche nos revela la crisis absoluta cuando ya ni nuestras teorías del conocimiento, ni nuestras éticas tienen un funda-

\footnotetext{
${ }^{14}$ Nietzsche, La gaya ciencia, 1987, Madrid, Akal, libro III, parágrafo 125.
} 
mento divino. ¿Qué hacer entonces? El hombre inventó nuevos juegos sagrados para remplazar a Dios, la nueva trinidad sobre la que se construyó la modernidad en Occidente: la Ciencia, el Estado y el Capital. Como escriben Horkheimer y Adorno:

La Ilustración [...] ha perseguido desde siempre el objetivo de liberar a los hombres del miedo y constituirlos en señores [...] El programa de la Ilustración era el desencantamiento del mundo. Pretendía disolver los mitos y derrocar la imaginación mediante la ciencia [...] Del mismo modo que se halla a disposición de los objetivos de la economía burguesa, en la fábrica y en el campo de batalla, así está también a disposición de los emprendedores, sin distinción de origen [...] La técnica [...] no aspira a conceptos o imágenes, tampoco a la felicidad del conocimiento, sino al método, a la explotación del trabajo de los otros, al capital. ${ }^{15}$

Pero ni la Ciencia, ni el Estado, ni el Capital pueden sustituir a Dios al prometer una vida más allá de la muerte ya que, como decía Sófocles, es la muerte la que detiene estas carreras y en la medida en que, a pesar de sus ensoñaciones, no pueden dar una respuesta a la tragedia de la muerte, la muerte se convierte en lo terrible por excelencia. Los juegos sagrados que inventamos pueden procurarnos protección, consuelo, ayuda, incluso promesas (criogenización) pero, cuando se habla de la muerte, estos juegos nos resultan eminentemente vacíos.

Thomas compara la antropología de la muerte en el África negra, en la que los muertos permanecen presentes en la vida social de los vivos, con nuestra sociedad; ${ }^{16}$ sugiere que el mundo del África negra es uno de acumulación de hombres, definida por el respeto a la vida y la aceptación de la muerte, en contraste con la sociedad occidental: acumulación de bienes, desprecio a la vida y terror a la muerte. Difunto, es, en definitiva, el que ha dejando de funcionar.

${ }^{15}$ Horkheimer y Adorno, La dialéctica de la Ilustración, op. cit., p. 59-60.

${ }^{16}$ Cfr. Louis-Vincent Thomas, Antropología de la muerte, op. cit., p. 621. 
La muerte hoy: entre el nihilismo, la represión y la ensoñación cientifica

Se ha impuesto, entonces, una perspectiva nihilista ante la muerte. Tal como escribía Wittgenstein: "mi muerte, mucho más que un suceso, será el fin del mundo, la conclusión definitiva de todo", visión, dirá Baudrillard, que define nuestra civilización: "La irreversibilidad de la muerte biológica es un hecho científico moderno. Es específico de nuestra cultura. Todas las otras afirman que la muerte comienza antes de la muerte, que la vida continúa después de la vida y que es imposible discriminar la vida de la muerte.” Pudiera ser que esa concepción nihilista de la muerte no sea tanto la causa, sino la consecuencia de la conversión de la muerte en tabú. Baudrillard y Thomas parecen converger en sus reflexiones sobre la represión de la muerte como explicación del control social. Escribe Thomas: "Hay una colusión manifiesta entre un sistema político que explota al hombre reducido a su función de productor-reproductor, tratado como producto e instrumento de consumo, y este mismo sistema en cuanto apoya su explotación al miedo, por lo tanto, en la negación de la muerte." ${ }^{17}$

Así, Baudrillard sugiere que el hecho de que la muerte sea ocultada, significa más bien que es omnipresente:

Sabemos lo que significan esos lugares inencontrables: si la fábrica ya no existe es porque el trabajo está en todas partes [...], si el cementerio ya no existe es porque las ciudades modernas asumen por entero su función: son ciudades muertas y ciudades de muerte. Y si la gran metrópoli operacional es la forma lograda de toda una cultura, entonces, simplemente, la nuestra es una cultura de muerte. ${ }^{18}$

En consecuencia, podemos relacionar lo dicho por Baudrillard, con el concepto de contraproducto de Ivan Illich: ${ }^{19}$ en nuestras socie-

${ }^{17}$ Ibid., p. 636.

${ }^{18} \mathrm{~J}$. Baudrillard, El intercambio simbólico y la muerte, op. cit., p. 146.

${ }^{19}$ Cfr. Ivan Illich, La convivencialidad, Barcelona, Posada. 
dades industriales, los medios de transporte, inmovilizan; los medios de comunicación, incomunican; los hospitales, enferman, de manera que la sociedad que hace de la muerte un tabú, es una sociedad letal: desde la industria bélica al monopolio de la muerte y violencia por parte del Estado (pena de muerte, brutalidad policial), hasta, como dice Baudrillard, la construcción de las necrópolis modernas, donde somos, "muertos en vida, arrastrados entre instantes insignificantes". Como decía Seattle sobre el hombre blanco: "su apetito devorará la tierra y dejará atrás sólo un desierto. La sola vista de sus ciudades llena de pánico los ojos del piel roja. Pero quizá esto es porque el piel roja es un salvaje y no entiende".

Por otro lado, la criogenización, que sería el sueño último de la ciencia, nos remite a la misma paradoja: en la medida en que quiere matar a la muerte, participa de esa idea que quiere rechazar. Matar al muerto, segregarlo, rechazarlo es impedir el intercambio simbólico, impedimento que se vuelve contra nosotros en angustia de muerte, de modo que "nosotros traficamos con nuestros muertos la moneda de la melancolía, los primitivos viven con los suyos bajo los auspicios del ritual y la fiesta". ${ }^{20}$

\section{Más allá de lo mortal y lo inmortal: sobre la amortalidad}

Cuando Edgar Morin reflexiona sobre el tema de muerte, lo hace superando las barras que normalmente condicionan toda pensamiento sobre lo mortal; lo hace eliminando las dicotomías que separan el pensamiento sobre el individuo y la especie, de manera que propone la noción de amortalidad; hace dos mil millones de años que existimos y nuestra amortalidad subyace en la evolución: "la individualidad sólo puede escapar a la muerte aceptando la metamorfosis, es decir, zambulléndose en una muerte-renacimiento". Así, a pesar del desprecio que sentimos hacia la especie, sobrevivimos en ella: "el hombre oculta su muerte como oculta su sexo y sus excrementos. Se presenta

${ }^{20}$ J. Baudrillard, El intercambio simbólico y la muerte, op. cit., p. 156. 
bien vestido [...] Se diría un ángel. Se comporta como un ángel para expulsar a la bestia. Se avergüenza de su especie: le parece obscena". ${ }^{21}$ Piensa que se trataría de dejar de odiar a la muerte: "trasmudar el odio a la muerte, no en odio a los otros o a sí mismo, sino en amor", de manera que coincide en lo fundamental con Thomas:

La muerte es a la vez horrible y fascinante [...] Horrible porque separa para siempre a los que se aman; porque el chantaje de la muerte es el instrumento privilegiado de todos los poderes; porque hace que nuestros cuerpos terminen por desintegrarse en una podredumbre innoble. Fascinante porque renueva a los vivos e inspira casi todas nuestras reflexiones y nuestras obras de arte, al tiempo que su estudio constituye un camino real para captar el espíritu de nuestra época y los recursos insospechados de nuestra imaginación. Puede decirse con verdad que amar la vida y no amar la muerte significa no amar realmente la vida. ${ }^{22}$

\section{La 'muerte-espectáculo'}

Si, como hemos dicho, la muerte es el tema tabú en Occidente, ¿cómo es posible su omnipresencia en los medios de comunicación? Procuraremos responder a la aparente paradoja al tiempo que intentamos dar una respuesta a la pregunta que se hace el cantante americano Jack Johnson: ¿Why don't the newscasters cry when they read about people who die?/ At least they could be decent enough to put just a tear in their eyes. ${ }^{23}$

Por medio de la semiótica, Thomas explica que la idealización, la purificación, (para liberar las angustias), la presentificación, (para hacer presente el tema en las conciencias) y la elaboración para la expresión artística, son diversas maneras de representar el concepto de la muerte. ${ }^{24}$ Pero hoy, los medios de comunicación tienen su propia

${ }^{21}$ E. Morin, El hombre y la muerte, 1944, Barcelona, Kairós, p. 355.

${ }^{22}$ L.V. Thomas, La muerte, op. cit., p. 154.

${ }^{23}$ J. Johnson, "The News", en línea, Internet 1 de marzo de 2006, disponible http://jackjohnson.com

${ }^{24}$ L.V. Thomas, Antropología de la Muerte, op. cit., p. 187. 
lógica discursiva sobre la muerte, una muerte, como diría Baudrillard, hiperreal: un mero espectáculo que se consume desde el sillón de casa. De nuevo, Baudrillard y Thomas coinciden: "Los medios de comunicación difunden sobre la muerte un discurso superabundante que la trivializa y oculta su dimensión esencial: muertes anónimas y lejanas, de interés estadístico o anecdótico, muertes espectaculares cuya repetición disminuye la repercusión emocional y cuya escenificación las diferencia radicalmente del drama vivido." ${ }^{25}$ De manera que consumimos un espectáculo visual permanente, que "cada día aporta su cuota de catástrofes, de crímenes, y de guerras, de vidas en peligro y de anuncios de fallecimientos". ${ }^{26}$

Recordemos cómo Baudrillard preguntaba a la Guerra del Golfo: “guerra ¿estás ahí?”, ante el espectáculo de la degradación del acontecimiento y su invocación fantasmal, regido por el principio de simulación que rige toda la información: la irrealidad estructural de las imágenes y su orgullosa indiferencia a la realidad. Así, nos preguntamos, muerte, ¿estás ahí? Retomando la idea de que hoy en Occidente la categoría de catástrofe se ha convertido en atentado, vemos que emerge ante nuestra mirada el patrón mediático que genera la hiperrealidad en estos casos. De manera que tanto en las catástrofes naturales como en los atentados, encontramos la misma producción, edición, control, invención de la realidad: si se trata de un atentado o de una catástrofe natural en un país del Primer mundo, la generación de la hiperrealidad sigue las siguientes pautas: ocultamiento de muertos (¿quién vio un cadáver o cuerpo sin vida el 11-S?); construcción narrativa consoladora y esperanzadora, que remite a la protección del Estado (banderas, jefe de Estado en la zona), de la Tecnología y del Capital (despliegues militares, ostentación tecnológica); si la catástrofe sucede en un país tercermundista, todo apunta a una especie de pornografía de la muerte: primeros planos de cadáveres, imágenes de dolor, zoom de miradas desesperadas, etc. Se perfila un modelo controlado, censurado, que además participa de la autodisuasión y de la automentira: a nosotros no nos pasan esas

${ }^{25}$ L.V. Thomas, La muerte, op. cit., p. 56.

${ }^{26}$ L.V. Thomas, Antropología de la Muerte, op. cit., p. 191. 
cosas. Así, no es que seamos víctimas del engaño, sino más bien todo lo contrario: "lo que necesitamos es el sabor afrodisíaco de la multiplicación de las falsificaciones, de la alucinación de la violencia, el goce de nuestra indiferencia, de nuestra irresponsabilidad". ${ }^{27}$ De manera que Baudrillard le diría a Johnson: no es indiferencia lo que sentimos: es goce de no estar ahí, de poder ver el espectáculo desde un sofá. La insensibilidad ante la muerte mediática e hiperreal, consecuencia de la forma indirecta en la que se capturan imágenes, porque el otro que muere no es 'tú', sino 'él': 'la muerte en tercera persona es la muerte en general, abstracta y anónima, un objeto como otro cualquiera, un objeto que puede describirse y analizarse... y que representa el colmo de la objetividad no trágica". ${ }^{28}$ ¿No es acaso sorprendente la similitud del periodista con la del científico clásico? Separación entre sujeto y objeto, descripción, análisis, falta de retroalimentación. Como decía Jankelevitch, objetividad no trágica; como diría Baudrillard, ausencia total de intercambio simbólico entre sujeto y objeto.

Tampoco podemos olvidar que la muerte se hace virtual por su repetición: "la sobresaturación de informaciones e imágenes que amenaza al consumidor, de alguna manera, lo anestesia y rara vez produce consecuencias prácticas". ${ }^{29}$ Cómo escribía Jankelevitch, la muerte es un objeto cualquiera, de manera que al presentador le es indiferente hablar de fútbol que de muerte. Thomas resume el efecto de las imágenes como "inofensivo en la sociedad que teme la muerte, ya que la reduce a información". ${ }^{30}$

En consecuencia, la 'muerte-espectáculo', es la manera en que se producen y consumen las imágenes sobre la muerte hoy en día, generando así una hiperrealidad de la muerte, construida en los medios y generada por modelos bien definidos, que acaba convirtiéndose en la versión de la realidad, contribuyendo a configurar así una sociedad de consumo inevitablemente presa de lo mediáticamente visible.

${ }^{27}$ J. Baudrillard, La guerra del golfo no ha tenido lugar, 1991, Barcelona, Anagrama, p. 86 .

${ }^{28}$ V. Jankelevitch, La mort, 1966, París, Flammarion, p. 22.

${ }^{29}$ L. V. Thomas, Antropología de la Muerte, op. cit., p. 192.

${ }^{30}$ Ibid., p. 193. 


\section{La semiótica de la muerte}

Una vez que hemos hablado de la hiperrealidad como lo específico de nuestras creaciones visuales - porque evidentemente todas las culturas son visuales, desde las pinturas de Altamira al delirio mediático de hoy-, podemos empezar a transitar los caminos de la significación de la muerte interpretando las imágenes, porque "las imágenes asociadas al cadáver son aquellas que sustituyen a la realidad, porque se ajustan al razonamiento que inventamos sobre la muerte". ${ }^{31}$

Una aclaración: el discurso periodístico no es un discurso original ni independiente respecto a la muerte: participa, recrea y reproduce el concepto occidental que hemos esbozado, aunque rara vez tenga conciencia de los fundamentos de sus propias representaciones; por ejemplo, es evidente que algo se les escapa a los periodistas que dicen que no muestran imágenes de las víctimas de Nueva Orleans por 'respeto al honor de las víctimas'. En lo que sigue, articulamos el análisis de las imágenes con el análisis del campo semántico para entender cómo los medios de comunicación construyen la realidad. Partimos de la recopilación de las imágenes del tsunami del 26 de diciembre del 2004, provocado por un temblor gigantesco, originado en las costas de Sumatra, Indonesia, que afectó a más de nueve países asiáticos, matando alrededor de 300.000 personas. ${ }^{32}$ También hemos reunido imágenes del huracán Katrina, que arrasó Nueva Orleans el martes 30 de agosto del 2005. ${ }^{33}$

${ }^{31}$ L. V. Thomas, El cadáver: de la biología a la antropología, 1989, México, FCE, 1989, p. 93. El subrayado es nuestro.

${ }^{32}$ J. Achenbach, "Quake: the next big one”, en National Geographic, 2006, abril, p. 140.

${ }^{33}$ J. Alter, "The other America", en Newsweek, Special Report, 2005, septiembre-octubre, p. 29. No se encontró en el artículo la cifra exacta del número de personas muertas. ¿No tendrá que ver con la idea de que no se quiere espantar a la gente por el hecho de ser un país 'primer mundista'? 
JUAN CARLOS HERRANZ / MÓNICA LAFON

De 'cuerpos', 'cadáveres'y 'restos'

En nuestra cultura estamos acostumbrados a todo tipo de eufemismos para referirnos a la muerte: preferimos decir 'cuerpo' para no hablar de 'cadáver'. De esto, se derivan los 'restos' de la persona. El 'cadáver', está en el margen entre una cosa y una persona. Nos hace reflexionar sobre el misterio de la muerte y el destino que nos espera.

En el artículo "Llegan a Chiapas cadáveres de víctimas de Katrina", se habla de los 'restos' de Adolfo Gómez Hernández (26 años) y de Julio Abarca Montes (48 años), que fueron trasladados desde Nueva Orleans hasta México; sus 'cuerpos', fueron transportados en un vehículo funerario. Al final del artículo, el periodista Oscar Gutiérrez agrega que las familias "esperan los restos mortales para ser velados e inhumados con llanto, dolor, y tristeza". ${ }^{34}$

Este artículo nos muestra el trato lingüístico de la muerte reducida a 'cuerpos' y 'restos' sinónimos para denominar un vacío, una materia sin vida. Pero también nos muestra el valor cultural del ritual funerario que garantiza devolver a las familias sus seres queridos, abriendo un espacio de reflexión para lo que puede ser la muerte causada por un desastre natural.

Pero, ¿qué pasa cuando los 'cuerpos', 'cadáveres' o 'restos' son olvidados o no se pueden identificar? Esto es lo que nos muestra una fotografía de Dean Sewell, ganador del Premio de Reportajes Gráficos del concurso fotoperiodístico World Press Photo 2005 (ver foto I). ${ }^{35}$ Observando el 'cuerpo' anónimo y olvidado, putrefacto, se comunica el terror de perder la identidad y la dignidad de la persona que ha muerto ya que no podrá ser identificada por la familia y nos remite a la total soledad de la muerte y la putrefacción. Thomas escribe que el cadáver es a la vez símbolo de ausencia y de 'putrefacción cercana'; ${ }^{36}$

${ }^{34}$ O. Gutiérrez, "Llegan a Chiapas cadáveres de víctimas de Katrina”, en línea, Internet 15 septiembre de 2005, disponible en http://www.universal.com.mx

${ }^{35}$ World Press Photo 2005, World Press Photo Foundation, Amsterdam, Holanda, p. 130.

${ }^{36}$ L. V. Thomas, El cadáver: de la biología a la antropología, op. cit., p. 7. 

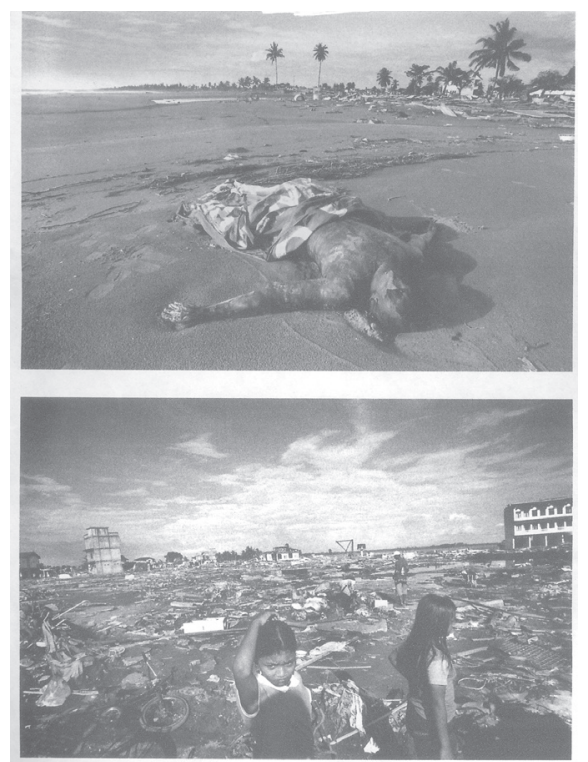

Dean Sewell

Foto I Austales, OculliAgencevo

[...] he aquí el esfuerzo, en todas las culturas por componer el cadáver. ${ }^{37}$

El manejo de la recaudación de los 'cadáveres' en situaciones de crisis expresa la visión cultural que la sociedad atribuye a la muerte. En el artículo del New York Times, "en la estela de desastres, descanso elude a muertos", la periodista Dewan hace referencia a este punto al informar que en Louisiana, las familias se quejaron por tener que esperar para la identificación de los 'cuerpos' de sus familiares: ¿Consuelo, protección y autentificación de la Ciencia?, preguntamos nosotros. Además aclaró que "las imágenes de cuerpos en descomposición abandonados en la calle han causado una profunda indignación de que muertos estadounidenses sean tratados como si fueran del Tercer Mundo". ${ }^{38}$ Esta cita corrobora el hecho de que las imágenes de muertos en un país desarrollado ofenden, son inaceptables. En un país con una visión de indestructibilidad, de poder, de inmortalidad, de racionalidad soberana, ¿cómo aceptar una derrota? ¿Cómo aceptar que hay cuerpos flotando en Nueva Orleans? En una de las pocas imágenes en las que hay cadáveres en dicha ciudad, aparece un ‘cuerpo' flotando en las calles. La nota dice que “mientras que los oficiales acababan de salvar a los sobrevivientes, empezaron a regresar a atender el número desconocido de muertos esparcidos

${ }^{37}$ Ibid., p. 11.

${ }^{38}$ S. Dewan, "Malas noticias parecerían fin del mundo: en la estela de desastres, descanso elude a muertos", México, The New York Times, suplemento del periódico Reforma, 22 de octubre. El subrayado es nuestro. 


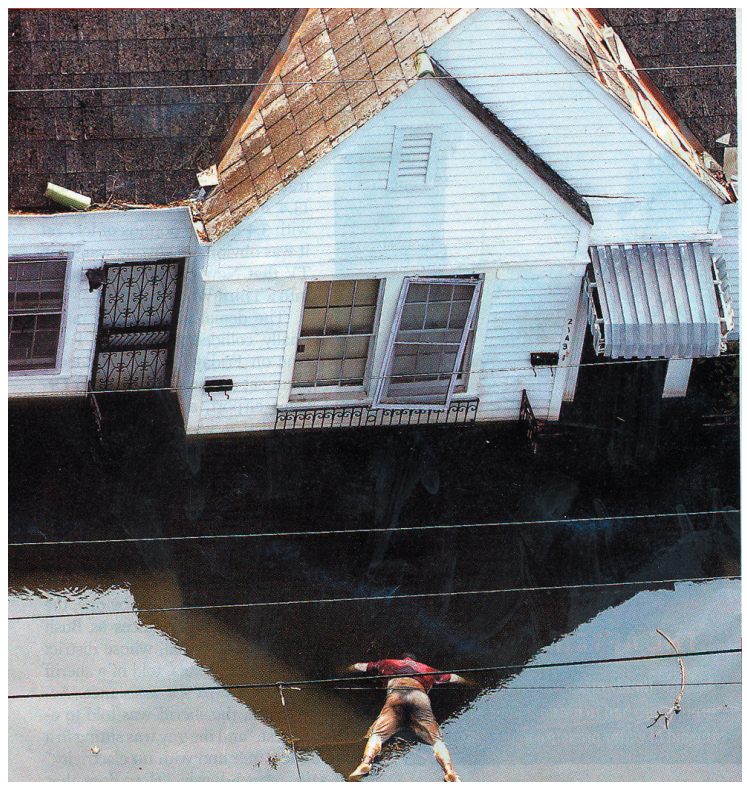

Foto II por la ciudad". ${ }^{39}$ Hasta hoy son desconocidas las cifras de muertos, tanto en el 11-S como en Nueva Orleans, en contraste con la aparente precisión matemática referente a los muertos por el tsunami de Indonesia. Además, compárese la distancia respecto a la imagen de la muerte en las fotos I (extrema cercanía) y II (lejanía, foto aérea).

\section{La semiótica de la fotografía en los medios impresos}

A continuación procuraremos pensar, de la mano de Roland Barthes algunos aspectos específicos de la fotografía de prensa. Su obra, Lo obvio y lo obtuso: imágenes, gestos, voces, nos presenta la manera en que la fotografía cambia de sentido dependiendo del contexto en el que se encuentra: es un producto y un medio, pero también un objeto por sí solo. Pero, además, la estructura de la fotografía se relaciona con el texto. Mientras que en el texto se analiza el lenguaje, en la fotografía se analiza el contenido. ${ }^{40}$

Barthes aclara que existen tres niveles para analizar una fotografía: el informativo, el obvio y el obtuso. El nivel informativo trata del mensaje que se comunica. El nivel obvio es el simbólico, lo que el autor

${ }^{39}$ J. Alter, "The other America", op. cit., p. 29. El subrayado es nuestro.

${ }^{40}$ R. Barthes, Lo obvio y lo obtuso: imágenes, gestos, voces, 1986, Barcelona, Paidós, p. 11-67. 


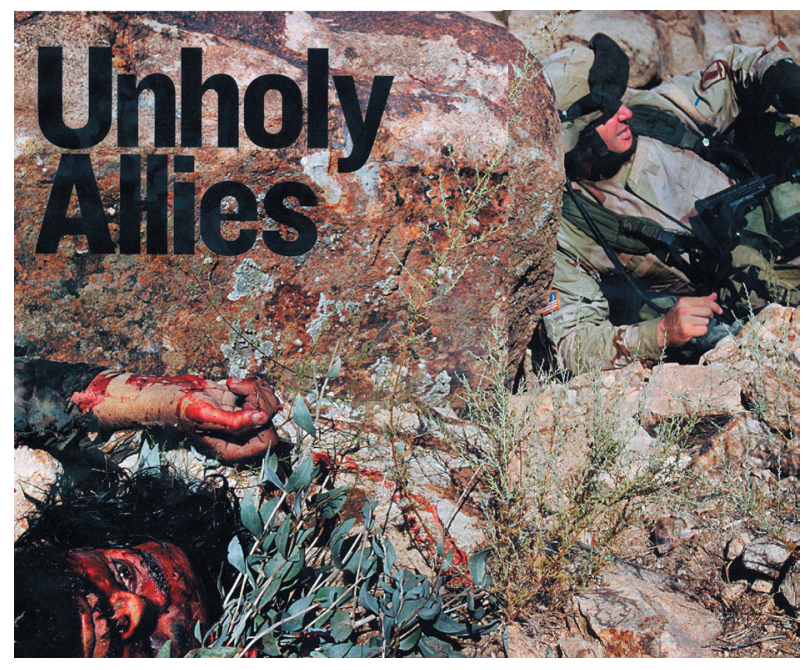

Foto III

y el lector sobreentienden. Por último, el más difícil de los niveles es el obtuso, ya que abre el sentido y "parece como si se manifestara fuera de la cultura, del saber, de la información". ${ }^{41}$ Para poder organizar nuestro análisis, examinamos a continuación la representación de las imágenes desde su connotación en los niveles de producción y recepción.

\section{La connotación en el nivel de la producción}

La compaginación, encuadre y elección, codifican el análogo fotográfico, mientras que el trucaje, la pose, objetos, y fotogenia, son parte de una connotación que modifica la realidad y el mensaje a partir de la edición de las mismas fotografías.

El trucaje es la connotación enmascarada perfecta, ya que la lectura denotada se crea en la fotografía, es real y objetiva. Un ejemplo es la foto III, donde en la portada del artículo 'Unholy Allies', aparece en la esquina inferior izquierda, la cabeza masacrada de un talibán, mientras que arriba y a la derecha, se ve un soldado norteamericano armado que espera para disparar. ${ }^{42}$ El encuadre y la elección de objetos,

${ }^{41}$ Op. cit., p. 32.

${ }^{42}$ S. Yousafzai, 2005, "Unholy Allies”, en Newsweek, Special Double Issue, septiembre-octubre, p. 17. 
ciertamente, nos remiten a la victoria de Estados Unidos en la guerra de Afganistán. Además, en cuanto al nivel obvio, contiene un sentido terrorífico por parte de la cabeza del muerto. Pensamos, más allá de lo dicho, que esta imagen es paradigmática de Occidente: representa una cultura que al mismo tiempo que le da la espalda a la muerte, es letal, mortífera, a la vez que nos remite a los juegos sagrados: el Estado (bandera en el brazo del soldado); Ciencia y Tecnología (equipo militar, metralleta, chaleco antibalas); y explicita en su texto: 'Unholy Allies'. En la imagen vemos todas las distinciones, todas las barras que configuran el pensamiento occidental: parte superior (norte): americano, gesto decidido, fuerza, limpieza; parte inferior (sur): tercer mundo, muerte, suciedad, terror. Pero al hablar de trucaje, nos llama poderosamente la atención que el soldado americano, en mitad del combate, no tiene ni una mancha en su equipo, está perfectamente afeitado, sus uñas lucen impolutas, su gesto casi sonriente.

Pensemos ahora en otro aspecto de la fotografía: la pose, en este caso, la actitud estereotipada que refleja los valores de un líder. Por

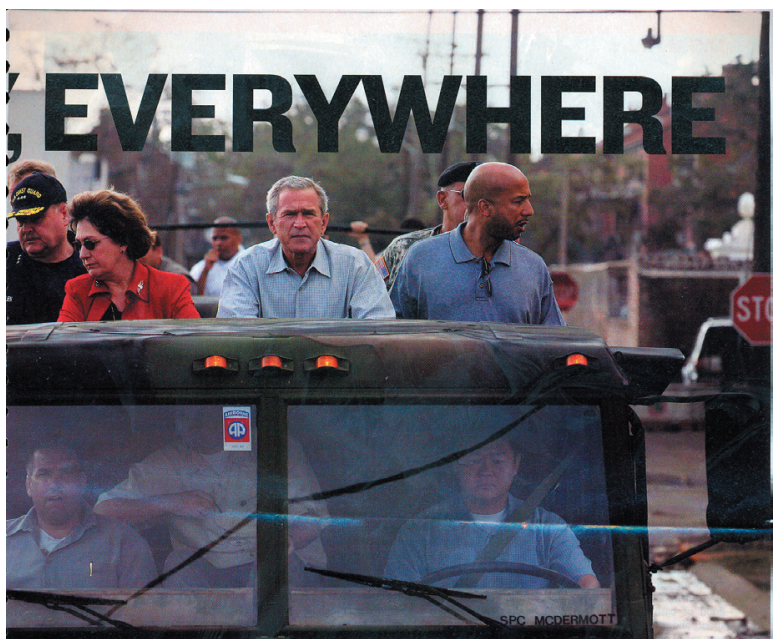

Foto IV ejemplo, en la foto $\mathrm{IV}$, el presidente $\mathrm{G}$. W. Bush aparece con el ceño fruncido, viendo hacia el frente, como si estuviera listo para afrontar con decisión la situación. ${ }^{43} \mathrm{Si}$ la leemos como una fotografía espontánea, se puede decir que el presidente no está consciente del que tomó la fotografía.

${ }^{43}$ J. Alter, 2005, op. cit., p. 29. 
Pero lo cierto es que está connotada, los fotógrafos saben cuando tomar la foto, escogiendo a los sujetos, que saben cuando posar para la cámara.

Pueden verse los mismos gestos, la misma pose en las fotos III, IV, VIII y IX: decisión, verticalidad, mirada al frente; en oposición a la pose de las fotos II y VII: derrota, horizontalidad, muerte, destrucción.

Una tercera forma de connotación son los objetos que comunican valores culturales. La foto $\mathrm{V}$ habla de ello. Junto con el título The Other America, ${ }^{44}$ aparece una anciana extremadamente delgada, de raza negra que espera su evacuación, cubierta en la bandera de Estados Unidos. La fotografía es en blanco y negro, una muestra más de una significación estética y dramática; asimismo, la anciana negra, una de las posiciones sociales más desventuradas en Estados Unidos, implicaría reconocer que hasta los individuos más desprotegidos tienen el apoyo del gobierno.

Por otra parte, la $f_{o-}$ togenia lleva el mensaje connotado en la imagen embellecida: iluminación, impresión, reproducción y movimiento. El ejemplo está claro en la portada de la revista Newsweek (foto VI) que muestra un primer plano de la cara, las lágrimas y los ojos de una niña. ${ }^{45}$ Ahora bien, la ideología, como objetivo de la noticia, puede condicionar la opinión del lector. Por ejemplo, el mensaje de la fotografía amplificada de la niña, que

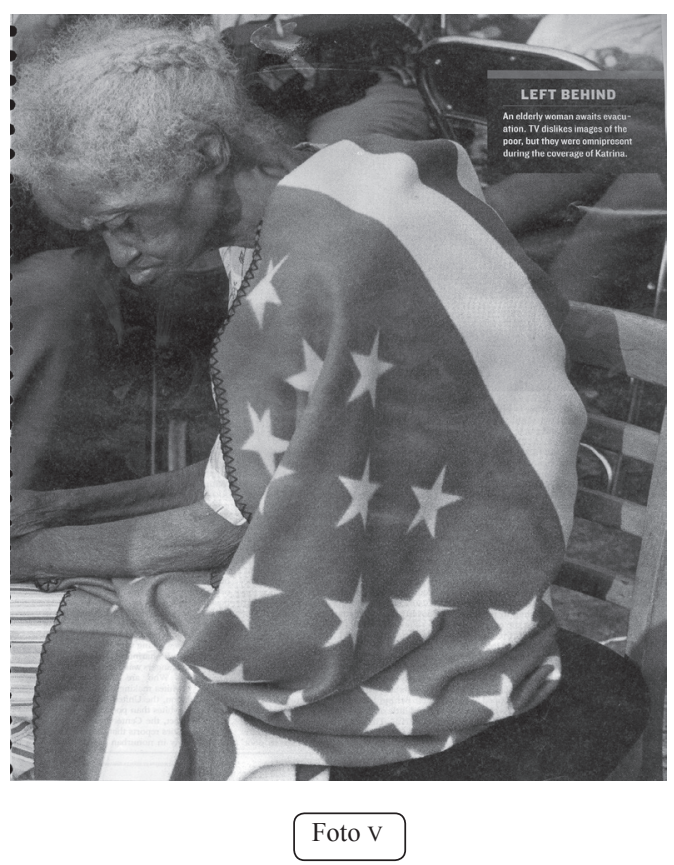




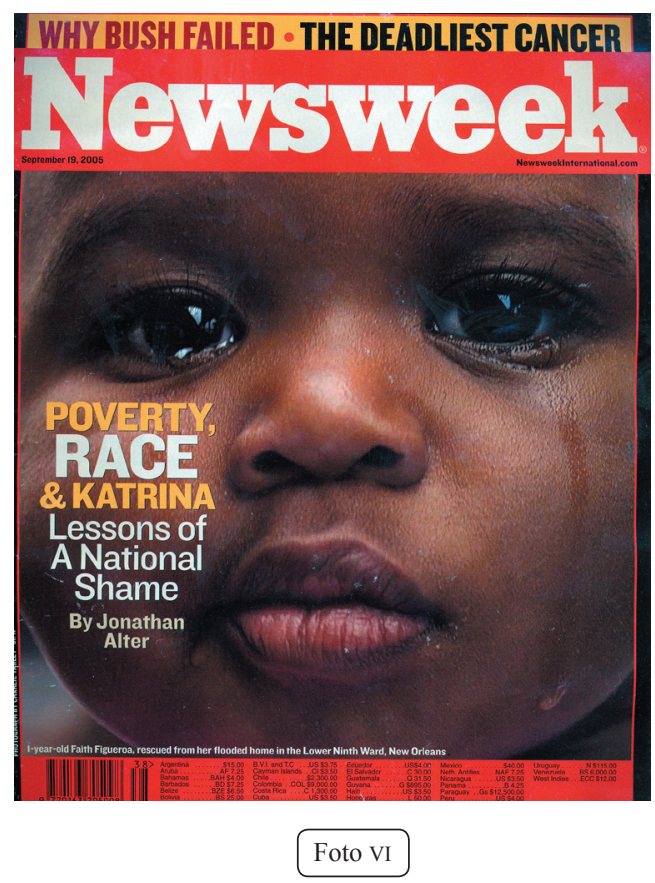

engloba el reporte especial sobre el desastre de Katrina, es claramente un mensaje de dolor del inocente, de la víctima, de lo imprevisible; pero de cierta manera, la imagen inspira más ternura que terror.

A partir del trucaje, la pose, los objetos y la fotogenia, las fotografías se van construyendo, para presentar una realidad inventada, tal como diría Watzlawick.

La connotación en el nivel de la recepción

Revisamos dos formas en las que una fotografía puede ser interpretada desde el punto de vista de la audiencia, partiendo del análisis de Barthes: el esteticismo y la sintaxis.

El esteticismo hace de la fotografía una referencia que remite sin ser evidente, al arte. La foto VII es una fotografía de Arki Datta ganadora del concurso World Press Photo 2005. ${ }^{46}$ En el nivel informativo, muestra a una mujer joven en cuclillas con la cabeza en el suelo y los brazos abiertos. A su izquierda, se enseña parte del antebrazo y la mano maltratada de un cadáver. En el nivel obvio, se comprende el sentimiento de la mujer, que parece estar pidiéndole una explicación a Dios, ya que ha muerto la persona que está frente a ella. Pero en un nivel obtuso, que no siempre se presenta en todas las imágenes, hay un grado

${ }^{46}$ World Press Photo, op. cit., p. 4. 


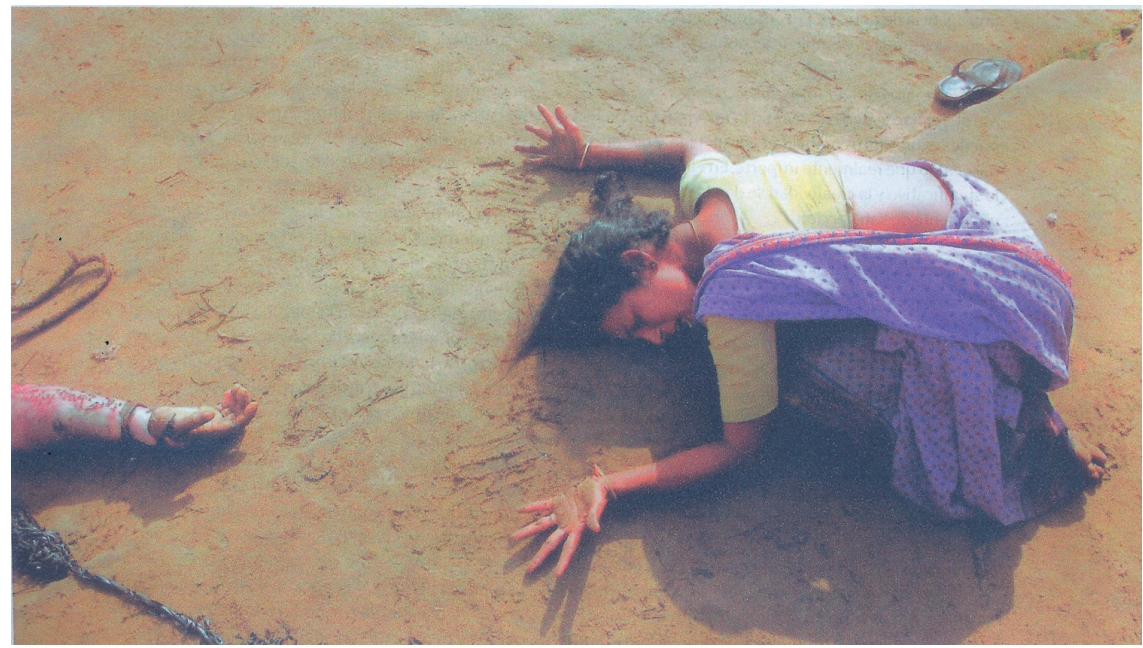

Foto VII

de misterio. Hay algo que intriga y vuelve imposible la descripción. Esto no sucede mucho en la prensa porque los mensajes tienden a ser más directos. Pero aquí surgen las preguntas: ¿de quién es la mano a la que la mujer lamenta?, ¿por qué, Dios?, tal como la mujer parece preguntar. Como dice Barthes, el sentido obtuso lleva cierta emoción "que se limita a designar lo que se ama, lo que se desea defender". ${ }^{47}$ Es difícil describirla porque "la lectura queda suspendida entre la imagen y su descripción, entre definición y aproximación”. ${ }^{48}$

El fotógrafo explica, sin embargo, que al acercarse de improviso a este acontecimiento, primero capturó la imagen completa del cuerpo hinchado, pero le pareció demasiado desagradable, y que no tendría propósito, ya que "la truculencia de una escena puede quitarle atención al sujeto principal de la misma, o a la fotografía en su conjunto" ${ }^{49} \mathrm{En}$ palabras de Barthes, esta connotación es lo que hace la imagen interesante y fuerte porque "el trauma es tributario de la certeza de que la

\footnotetext{
${ }^{47}$ R. Barthes, op. cit., p. 59.

${ }^{4}$ Ibid., p. 61.

${ }^{49}$ World Press Photo, op. cit., p. 4.
} 


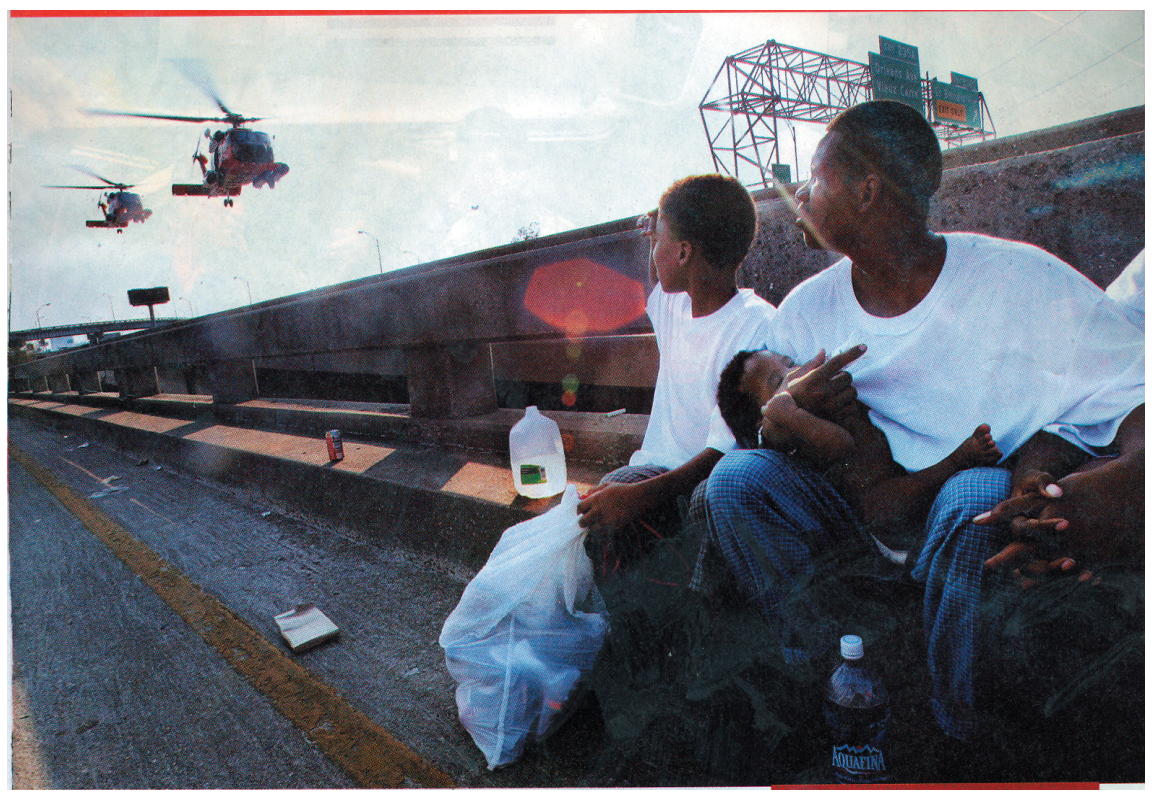

Foto VIII

escena ha tenido lugar de forma efectiva [...] pero [en] la foto traumática, de [...] catástrofes, muertes violentas, en vivo: el foto-impacto es insignificante en su estructura". ${ }^{50}$

Cuando se le preguntó a Arki Datta en cuanto a su estado emocional en los desastres naturales, explica que "la cámara actúa como una especie de barrera emocional" ya que finalmente, es su trabajo. Aquí se nos plantean cuestiones éticas: ¿cuál debería ser el comportamiento del reportero en estos casos?; ¿de quién es la fotografía en última instancia? ¿de la mujer anónima lamentando un cuerpo anónimo o de Arki Datta? Como responde Barthes, la fotografía tiene una manera de "hacer un lenguaje de un objeto inerte y transformar la incultura de un arte mecánico en la más social de las instituciones" ${ }^{51}$ Por esta misma razón muchas de las fotografías han pasado a la historia formando ciertos conceptos que se impregnan en la conciencia colectiva.

${ }^{50}$ R. Barthes, op. cit., p. 26.

${ }^{51}$ Ibid., p. 27. 


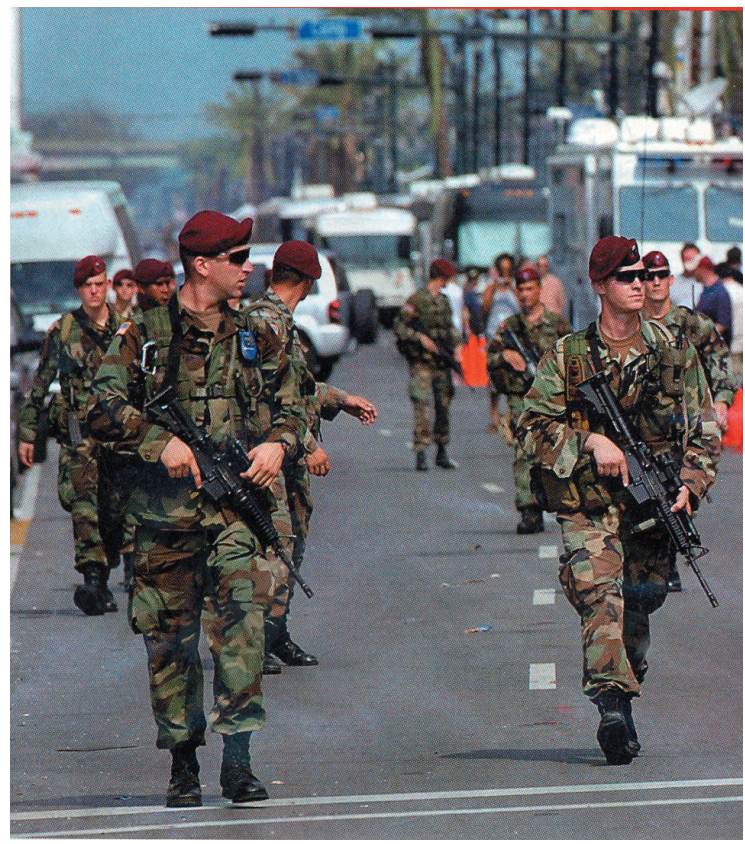

Foto IX
Por último, hablaremos de la sintaxis, que es fundamental para comprender la fotografía de prensa: las fotografías no se presentan aisladas, sino que en su conjunto constituyen toda una narratividad, construcción de los 'hechos', por lo que tanto las secuencias como los encadenamientos en las que se encuentra cada fotografía son pistas para su lectura. Hemos visto cómo se construyen estas narrativas: si en el

Katrina todo respondía a una estrategia tranquilizante, la sintaxis fotográfica del tsunami de Indonesia nos remite a una historia de terror. Compárese la construcción sintáctica de las fotos IV, V, VIII y IX, con la de las fotos II y VII.

Así, podemos entender que la connotación de las fotografías nos transmite valores que comprenden un sistema de códigos culturales ya establecidos a la hora de crearlas y percibirlas, de manera que lo que acaba desapareciendo es la realidad misma: "toda realidad es absorbida por la hiperrealidad del código y de la simulación. Las finalidades han desaparecido, son los modelos los que nos generan. Ya no hay ideologías, sólo hay simulacros". ${ }^{52}$ Como decíamos, aparece el código de lo real, máquina programática.

${ }^{52}$ J. Baudrillard, El intercambio simbólico y la muerte, op. cit., p. 6. 


\section{Conclusiones}

Si en este punto preguntamos, ¿qué es, entonces, lo que está en juego en las fotografías de prensa en las catástrofes naturales que hemos venido analizando?, se podría responder que se trata, ni más ni menos, de representar el concepto de razón que define a la civilización occidental y los juegos sagrados que la constituyen y engalanan. Como hemos visto, una catástrofe natural es un atentado contra la $f e$ en una racionalidad absolutamente soberana y previsora. El psicoanálisis profundizó en el estudio de la negación de la realidad como una forma de interpretación de la realidad: así, vimos que los medios se constituyen como elemento fundamental para esas interpretaciones, mediante las funciones que hemos esbozado: negación, automentira, protección; se trata, en definitiva, de una estrategia tranquilizante tanto cuando se niega la catástrofe en un país del Primer mundo, como en el caso de la pornografía del terror y la muerte si la catástrofe tiene lugar en un país del Tercer mundo: al Otro, -a la otra racionalidad-, sí le ocurren esas cosas. Nuestra cultura, entonces, piensa la muerte precisamente de forma contraria a Heidegger: la sociedad occidental, incluido evidentemente el discurso mediático, se caracteriza por un modo rehuyente y encubridor, tal como diría el filósofo de Messkirch. Hemos visto cómo se produce este modo rehuyente: desde la negación hasta la conversión de la muerte en muerte-espectáculo, creada por la máquina programática, lo que da paso a la desaparición misma de la realidad, emergiendo así una hiperrealidad creada por códigos bien definidos, porque quedó claro que las imágenes no reflejan, sino que inventan lo real.

Este ensayo tendría finalmente el propósito de invitar al lector a pensar la vida y la muerte en su complejidad, más allá de la trivialización cotidiana de la muerte en todos los aspectos de nuestra cultura, $\mathrm{y}$, especialmente, en los medios de comunicación, porque si Weber habló de la jaula de hierro burocrática, la posmodernidad apunta más bien a una jaula mediática: se trata entonces de romper esos barrotes y elaborar un pensamiento autónomo sobre la muerte, porque como 
se apuntó en el texto, la represión de la muerte no es sino fuente de dominio. Recordemos a Montaigne: "la premeditación de la muerte es premeditación de la libertad. El que aprende a morir, aprende a no servir. El saber morir nos libera de toda atadura y coacción." 53

Se trata de una invitación al pensamiento autónomo. En consonancia con lo anterior, se invita también a un pensamiento poético sobre la muerte, porque tan sólo desde la poesía se puede pensar que aquellos seres que amamos y se fueron, a la vez están y no están, se marcharon y permanecen, callan y hablan a diario con nosotros.

${ }^{53}$ Montaigne, Ensayos, 1996, Madrid, Cátedra. 
La reproducción total o parcial de este artículo se podrá hacer si el ITAM otorga la autorización previamente por escrito. 